\title{
Effect of the use of Information Technology, Anntensity of Users,Users of Expertise of the quality of Accounting Information
}

\author{
Indah Rahayu Lestari, BerlianKarlina, Anita WahyuIndrasti
}

\begin{abstract}
Entering the era of globalization, Indonesian MSMEs have experienced growth by the years. With the development of MSMEs, the obstacles that are often faced are financing and capital issues. The limited access to credit is largely due to financial reporting. The development of accounting information that is not only used by large companies, the MSMEs also apply accounting information in the business. Information is the result of data processing that gives meaning and benefits. Thus, information systems have an important role in relation to the quality of accounting information. The growing information system used then the resulting information will be better and better to improve the quality of accounting systems. This study shows how the influence of the use of information technology, user expertise, intensity of use on the quality of accounting information. Samples in this research are MSMEs in Indonesia. The results of this study are: the use of information technology has a significant and positive effect on the quality of accounting information, user expertise does not affect the quality of accounting information, and the intensity of usage has a significant positive effect on the quality of accounting information.
\end{abstract}

\section{Introduction}

Economic development that is being actively implemented by the Indonesian government aims for the welfare of the people. One of them by providing guidance and developing micro, small and medium enterprises (MSMEs) [1]. Today even economic actors, especially MSME players, must have a strong strategy so that the products and services produced have competitiveness in the market. With the empowerment of MSMEs, it is expected that MSMEs in Indonesia can produce superior products and services that are able to compete with large industries [2].

Entering the era of globalization, MSMEs in Indonesia continue to experience growth from year to year. According to data from the Central Statistics Agency (BPS) the prediction of the number of micro, small and medium enterprises in Indonesia in 2018 is 58.97 million business units, consisting of 58.91 million units of small businesses, 59,260 micro-enterprises. And medium businesses as many as 4,987 units [3].

The obstacle that often affects the development of MSMEs is the lack of access to capital. Based on a World Bank survey conducted on companies in 2009

Revised Manuscript Received on July 05, 2019.

Indah Rahayu Lestari,

Faculty of Economics and Business, Universitas Budi Luhur,

indah.rahayu@budiluhur.ac.id
(Mourgane, 2012), it shows how access to capital financing is the biggest obstacle in inhibiting investment in the development of MSMEs in Indonesia, followed by problems in the informal sector, high electricity tariffs, and political instability. credit financing for MSMEs can be seen from the allocation of loans received by the sector. The Asia Development Bank (ADB, 2013)shows that MSMEs only receive Rp. 579.3 trillion in bank loans, or only18.9 percent of them of all outstanding bank loans, and 6.4 percent of total GDP in 2012 [4].

Accounting information is not only used in large companies, but accounting information systems are also applied to MSMEs. The role of accounting information for MSMEs is almost the same as that applied to large companies. Among other things are used economic decision-making regarding business developments, pricing, financial reporting in accordance with accounting standards [5].

Technology Acceptance Model (TAM) believes that the use of information systems will improve the performance of individuals and organizations. With the increase in performance, the quality of information is getting better [6].

DeLone and McLean (2005) found that the better the quality of information systems, the more users will use the information system. The better the quality of the system and the output of an information system, the intensity of usage will increase [7].

\section{Literature Review}

\subsection{Quality of Accounting Information}

Accounting information is quantitative information about economic entities that are useful for making economic decisions and making choices between alternative measures (Belkauoi, 2006).The quality of information is a measurement of the content of accounting information systems (Ong ET. Al, 2009: 399). Negashet. al. (2003: 758) explains that the quality of information is a function that concerns the value of output information generated from the system [8]

In accounting information is the output of an accounting information system. The accounting information that will be used for decision making. The decision in question is an economic decision that is useful in making choices to decide what actions to take [9].

Based on $\begin{aligned} & \text { Financial } \\ & \text { Accounting }\end{aligned}$
(2018), the quality of

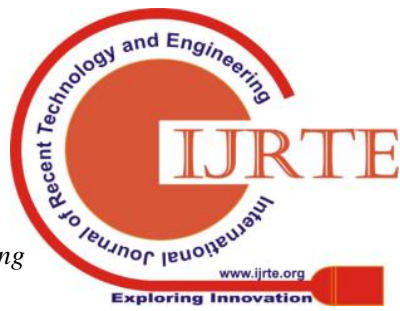


accounting information is a normative measure. Use of Accounting Information that needs to be realized, so that it can fulfill its objectives. Quality information meets the characteristics of the characteristics: understandable, relevant, materiality, reliability, substance to outperform, consideration of health, completeness, comparability, timely, balance between costs and benefits [10].

\subsection{User of Accounting Information Technology}

An accounting technology user are users of computer technology related to the processing of data to become an information and distribution process limits the data / information is within the space of time (Harfan Hamdani, 2012) [11]. Measures of the use of information technology can be seen, as follows:

1. Has enough utilities

2. Internet Network

3. Protection of computer networks

4. The computerized accounting processes

5. Processing data using software

6. Integrated information system

7. Regular equipment maintenance schedule

Information technology users support the company's operational activities which are the main needs as one of the competitive strategies. The use of information technology requires the wearer to use the system to be able to achieve company goals by utilizing information technology. Apart from being computer technology to process and store information, information technology also functions as a communication technology for information dissemination [12].

\subsection{User Skills}

Users need to know and understand the information technology used by companies in information systems. With a good understanding of the user, the flow of information will be able to interpret well, and is expected to provide good quality information [13-15].

User skills are behaviours and actions carried out with predetermined targets, according to the ability of the user during the system implementation process(Mardiah Rahmi, 2013) [16-18].

User expertise related to knowledge and skills possessed by users in operating computers using accounting information systems. According to Griffin (2004: 23) a measure of user expertise can be measured, as follows:

2. Training

3. Experience

\subsection{Usage intensity}

The development of information technology that continues to make technology easier to understand and use. This development also occurs in computers from time to time. Initially the computer used a separate CPU with a monitor, then continued to grow until now the tablet PC can
1. Education

be carried everywhere. This development makes computers more familiar to the community, and the intensity of their use becomes more frequent [19-21].

Ease of technological development, causing technology to be used at any time by the user. This can increase the intensity of computer users. To meet the job target, the user especially makes financial statements will use the information system intensively until the work can be completed quickly and precisely [22-24].

\section{Research Methodology}

In accordance with certain same characteristics, required MSMEs in Indonesia, this technique is selected to ensure that only the samples have certain elements. If the sample can be retrieved from data, it can also be called convenience sampling (Sugiyono, 2016).The sample is part of the population used to infer or describe the population. The sample in this research is a food and beverage entrepreneur or kind of Café or Restaurant in Indonesia as many as 70MSMEs [25].

Researchers used the PLS method to analyse this multivariate model. The models consist of four exogenous latent variables, namely accounting knowledge, comprehension accounting, owner of education, owner experience and application of financial statements. The models proposed by the researcher are analyzed usingSmartPLS3.2.1 application [26].

\section{Research Result}

The results of the tabulation of questionnaires that have been inputted using Microsoft software are exported to Smart PLS 3.2 application to be further analysed. The data used is complete data. Out of a total of 70 respondents. These 70 respondents the data is used for measurement models and structural model analysis [27] .

The measurement model for validity and reliability tests, the model and path coefficient for model equation coefficient of determination, can be seen in the picture below:

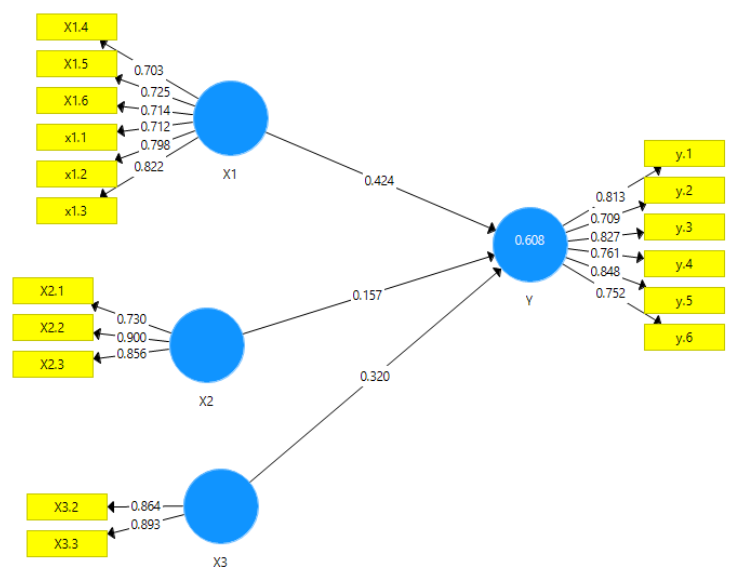

Figure 1.Result Display Picture of PLS Algorithm

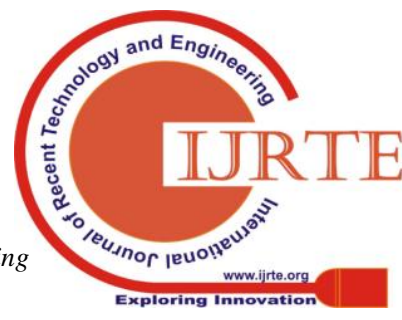




\subsection{Reliability Test}

The outer data loading shows that have values above 0.70 so the results are not too needy.

If traditional research uses Cronbach's alpha value as a reference, then use different sizes to determine reliability. Composite reliability values are used instead (Bagozzi\& Yi, 1988).Hair (2014) requires that the composite reliability value should be above 0.70 or 0.60 if the study is exploratory.

\section{Table 1 Composite Reliability}

\begin{tabular}{|c|c|c|}
\hline \multicolumn{3}{|c|}{ Composite Reliability } \\
\hline \multicolumn{2}{|c|}{ 模 Composite Reliability } & \multirow{3}{*}{$\begin{array}{r}\mid ⿴ 囗 玉 \text { Matrix } \\
\text { posite Rel... } \\
0.883\end{array}$} \\
\hline & Comp & \\
\hline $\mathrm{x} 1$ & & \\
\hline $\mathrm{x} 2$ & & 0.870 \\
\hline X3 & & 0.871 \\
\hline Y & & 0.907 \\
\hline
\end{tabular}

The table above shows variables having an AVE value above 0.50 .So, it can be concluded that the construct has good validity.

The structural model in the PLS is evaluated by the dependent variable and the path coefficient, which is then assessed, whose significance is based on the statistics of each path [28].

\subsection{Hypothesis testing}

To assess the structural model in testing the structural model, it can be seen from the statistical values of the dependent variable in the Path Coefficient table in the SmartPLS Output below:

\section{Table 2. Path Coefficients}

\begin{tabular}{|c|c|c|c|c|c|c|}
\hline \multicolumn{2}{|c|}{ 直 Mean, STDEV, T-Values, P-Valu... } & \multicolumn{2}{|c|}{ 圊 Confidence Intervals } & \multicolumn{2}{|c|}{ 囯 Confidence Intervals Bias Cor... } & \multirow{2}{*}{$\begin{array}{c}\text { Samples } \\
\text { P Values } \\
{[3]}\end{array}$} \\
\hline & Original Sampl... & Sample Mean (... & Stan & Idard Error ... & T Statistics $(\mid 0 \ldots .$. & \\
\hline$X 1 \rightarrow Y$ & 0.424 & 0.434 & & 0.119 & 3.550 & 0.000 \\
\hline$X 2 \rightarrow Y$ & 0.157 & 0.159 & & 0.132 & 1.190 & $0.235[4]$ \\
\hline$X 3 \rightarrow Y$ & 0.320 & 0.312 & & 0.107 & 2.989 & 0.003 \\
\hline
\end{tabular}

$\mathrm{T}$ (2-tailed) test results with a 5\% significance level shown in the Table above shows that:

\subsubsection{Testing the first hypothesis}

From the table above, you can see the final sample estimate LS is 0.424 with significance below $5 \%$ indicated by the value of $t$ statistics 3,550bigger than t-table value of 2,0017 .The original value of sample estimate positively indicates that used of information accounting has a positive effect on accounting information quality. Based on the results of there gression can be concluded that the first hypothesis is accepted.

\subsubsection{Testing the second hypothesis.}

From the table above the can be seen from the original sample estimate LS is 0.157 with a significance below $5 \%$ indicated by the value of $t$ statistics of 1,190issmallerthan the t-table value of 2.0017.The original value of sample estimate positively indicates that the expertise of the user has a positive effect on the accounting information quality. Based on the results of the regression can be concluded that the second hypothesis rejected.

\subsubsection{Testing the second hypothesis.}

From the table above, they can be seen as the original sample estimate LS is 0.320 with a significance below $5 \%$ it is indicated by the value of $t$ statistics of 2,989 is greater than the t-table value of 2.0017.The original value of sample estimation positively indicates that intensity usage has a positive effect on accounting information quality. Based on the results of the regression can be concluded that the second hypothesis accepted.

\section{Conclusion}

Based on the results of this study, the following conclusions are obtained:

1. Variable used of information accounting positively affect on accounting information quality.

2. Do is comprehension accounting variables not effect on accounting information quality.

3. Variable level of intensity usage affect on accounting information quality.

Ethical clearance - Not required

Source of funding- Self

Conflict of Interest - Nil

\section{References}

[1] Abdulkadir Muhammad dan Rilda Murniati. Segi Hukum Lembaga Keuangan dan Pembiayaan. Bandung: Citra Aditya Bakti, 2000.

[2] Belkaoui, Ahmed Riahi. Teori Akuntansi, Edisi 5 Buku 1. Terj. Ali Akbar Yulianto dan Rismawati Dermauli. Jakarta: Salemba Empat, 2006.

3] Darmawan. Metode Penelitian Kuantitatif. Bandung: Remadja Rosdakarya, 2013.

235[4] E. Kieso, Donald, Jerry, J Weygandt and Teery D. Warfield Accounting Principles, Edisi 12. Jakarta: Salemba Empat, 2007.

[5] E. Kieso, Donald, dkk. Akuntansi Intermediate, Edisi 12, Jilid 1. Jakarta: Erlangga, 2008.

[6] Hair Jr, et al. Essential of Business Research Method USA, 2014.

[7] Harahap. Analisis Krisis Atas laporan Keuangan, Edisi Pertama Cetakan Ketiga. Jakarta: Raja Grafindo Persada, 2007.

[8] Hoetomo. Kamus Lengkap Bahasa Indonesia. Jakarta: Mitra Pelajar, 2005.

[9] Ikatan Akuntansi Indonesia. Standar Akuntansi keuangan. Dewan Standar Akuntansi Ikatan Akuntansi Indonesia, Jakarta, 2017.

[10] Keraf, Gorys. Diksi dan Gaya Bahasa. Jakarta: Gramedia Pustaka Utama, 2001.

[11] Muljono, Teguh Pudjo, Drs, Akuntan. Analisis Laporan Keuangan Untuk Perbankan. Jakarta: Djambatan, 1990. 
[12] Poerwadarminta. Kamus Umum Bahasa Indonesia. Jakarta: Balai Pustaka, 2006

[13] Poespoprodjo. Pengantar Dialektika dan Ilmu. Bandung: Remadja karya, 1987.

[14] Rudianto. Pengantar Akuntansi Adaptasi IFRS. Jakarta: Erlangga, 2012 .

[15] Santoso, Singgih. Statistika Induktif Edisi 5. Yogyakarta: BPFE, 2012.

[16] Sugiyono. Metode Penelitian Pendidikan (Pendekatan Kuantitatif dan Kulaitatif dan R\&D). Bandung: Alfabeta, 2015.

[17] Suwardjono. Teori Akuntansi: Pengungkapandan Sarana Interpretatif. Edisi Ketiga BPFE, Yogyakarta, 2010.

[18] Suwardjono. Pengantar Akuntansi. Edisi Ketiga BPFE, Yogyakarta,2014.

[19] Anggraini, Gama Risti. Kamaludin dan Sri Adji Prabawa. Pengaruh dan Faktor-Faktor Internal dan Eksternal Perbankan Terhadap Stratergi Pemberian Kredit Sebagai Upaya dalam Meminimalkan Nilai NPL. Jurnal Ilmiah Manajemen Vol. 15. No 5, 2013.

[20] Divianto Febrianty. Pengaruh Pemahaman Pelaku UMKM dalam Menyusun Laporan Keuangan terhadap Implementasi Laporan Keuangan Berdasarkan SAK ETAP dengan Persepsi Pelaku UMKM sebagai Moderating Variabel. International of Journal of Social Science and Business Vol 1(3) pp. 166-167, 2017.

[21] Irwan Nurkholis. Tingkat Pendidikan, Skala Usaha, Pengalaman Usaha, dan Masa Jabatan Berpengaruh terhadap Penerapan Laporan Informasi Akuntansi Pada Usaha Kecil dan Menengah. Universitas Dian Nuswantoro Semarang, 2014.

[22] Kurniawansyah. Penerapan Pencatatan Akuntansi dan Penyusunan Laporan Keuangan Berdasarkan SAK ETAP pada UMKM Desa Gembongsari Kecamatan Puro Kabupaten Banyuwangi, 2016.

[23] Mulyani, Sri. 2014. Faktor-Faktor yang Mempengaruhi Kualitas Laporan Keuangan pada UMKM di Kabupaten Kudus, Vol 11 No.2, Oktober 2014.

[24] Nanang Shon Hadji, dkk. Penerapan Penyusunan Laporan Keuangan pada UKM Berdasarkan SAK EMKM di Surabaya, Universitas Islam Madura, 2017.

[25] Putra, H. A., dan Kurniawati, E. P. Penyusunan Laporan Keuangan untuk Usaha Kecil dan Menengah (UKM) Berbasi Standar Akuntansi Keuangan Entitas Tanpa Akuntabilitas Publik (SAK ETAP). Jurnal Pekan Ilmiah Dosen FEB (halaman. 547-580). Salatiga: Universitas Kristen Satya Wacana: Fakultas Ekonomika dan Bisnis, 2012.

[26] Rahmawati dan Puspasari. Implementasi SAK ETAP dan Kualitas Laporan Keuangan UMKM Terkait Akses Modal Perbankan, 2017.

[27] Satyo. UKM dan Kebutuhan Standard, Media Akuntansi, 4 (XII), 4, 2005.

[28] Suhartati Titi, Warsini Sabar, Implementasi Standard Akuntansi Entitas Tanpa Akuntabilitas Publik (SAK-ETAP) dalam Proses Akuntansi dan Penyusunan Laporan Keu-angan Pada Usaha Mikro, Kecil dan Menengah (UMKM). Jurnal Akuntansi, Keuangan dan Perbankan, 2014. 